\title{
Design Choices and Urban Forest Characteristics in Raleigh, North Carolina, U.S. Parking Lots
}

\author{
Evan M. Keto, Melissa R. McHale, George R. Hess, Bronson P. Bullock, and Gary B. Blank
}

\begin{abstract}
Trees provide important environmental, economic, and social benefits that can help to offset the negative effects of parking lots. Many cities recognize that adding space for trees in parking lots is beneficial and have created regulations that dictate minimum requirements for tree planting. However, it is not clear if tree plantings in parking lots achieve the urban tree canopy goals initially imagined by these communities. The study authors sampled parking lot trees in Raleigh, North Carolina, U.S., to determine how species composition and urban forest structure vary with respect to parking lot size, shape, and design. Using a two-stage cluster sampling scheme, Raleigh's parking lots were found to contain 44,000 $\pm 24,000$ trees (95\% confidence interval). No differences in tree composition were explained by the size or shape of the parking lots. Planting spaces within the parking lot that were preserved during construction were found to have more trees, canopy, and basal area per hectare than designed planting spaces in which the number, spacing, and species of trees were prescribed. Among designed planting spaces, large, linear rows had greater canopy and basal area per tree but fewer trees per hectare than smaller, circular islands. These results suggest that decisions made during the design process may have lasting effects on the structure and function of this portion of the urban forest.

Key Words. Automobile; Car Park;Environmental Impacts; Parking LotDesign;Transportation;TreePlanting;TreePreservation;Urban Forest Structure.
\end{abstract}

Impervious cover in cities has been shown to have detrimental effects on urban watersheds; as little as $10 \%$ impervious cover can negatively affect water quality, with $30 \%$ contributing to significant degradation of the watershed (e.g., Arnold and Gibbons 1996). Although there are many forms of impervious cover-including buildings, sidewalks, and driveways-parking lots alone can account for a large percentage of urban areas. Parking lots were estimated to comprise $4.97 \%$ of urban land in the Upper Great Lakes region while total area of parking has been shown to cover from $5 \%$ to $18 \%$ of many cities across the U.S., including Sacramento, California; Salt Lake City, Utah; Chicago, Illinois; and Houston, Texas (Akbari et al. 1999; Akbari and Rose 2001a; Akbari and Rose 2001b; McPherson 2001; Rose et al. 2003; Davis et al. 2010;). In areas of high coverage, parking lots are a significant source of oil, grease, nutrients, and carcinogenic sealing compounds (Stenstrom et al. 1984; Hope et al. 2004; Mahler et al. 2005), and contribute to stream sedimentation and bank erosion (Hammer 1972; Albanese and Matlack 1998).

Besides water quality effects, parking lots have many other negative environmental, social, and economic effects. For instance, pavement contributes to the urban heat island effect (Asaeda et al. 1996; Grimmond and Oke 1999; Celestian \& Martin 2004), and automobiles create air pollution while moving through parking lots as well as when they are parked (Hahn and Pfeifer 1994; Scott et al. 1999; EPA 2007). Furthermore, large amounts of parking and sprawling patterns of development have been blamed for reducing the density of cities and subsequently impairing the street life and the social and economic character of urban areas (Jackson 1996; Kunstler 1996; Shoup 2005).
Trees can provide a wide range of benefits that may help offset the negative effects of parking lots. Shade from trees reduces damaging ultraviolet rays (Heisler and Grant 2000), solar degradation of pavement, and thus the need for resurfacing (McPherson and Muchnick 2005). Trees moderate temperatures of pavement, air, and automobile cabins and gas tanks, reducing precursors of ozone formation (Scott et al. 1999). Canopies absorb ozone and intercept particulate matter (Beckett et al. 1998; Nowak et al. 2006), sequester carbon dioxide (Rowntree and Nowak 1991), and intercept and retain stormwater (Xiao et al. 2000). Anderson and Stokes (1989) showed that well-maintained trees and other vegetation in parking lots improved people's perceptions of an area's comfort as well as the lot's attractiveness and security. Furthermore, customers preferred shaded parking spaces in a California lot during the summer (Scott et al. 1999) and were willing to pay more for goods from, return more frequently to, and stay longer in shopping centers with mature trees and shrubs in their parking lots (Wolf 2009).

Many of these benefits depend on the number, size, and species of trees used (Nowak 2008). Trees with larger canopies have greater effects on aesthetics, water quality, shading, and air quality (Schroeder et al. 2009). Additionally, larger trees have a higher benefit-to-cost ratio than smaller trees (McPherson et al. 2005; Schroeder et al. 2009). Tree species can vary dramatically in mature size, lifespan, aesthetic characteristics, resistance to pests and diseases, and emissions of ozone-forming volatile organic compounds and pollen. The growth of trees in parking lots is affected by many factors, and recent studies have focused on the importance of soil volume and quality (Grabosky and Gilman 2004; Celestian and Martin 2005; Smiley et al. 2006). There- 
fore, to understand how to maximize the benefits of a city's parking lot trees, analysts can begin by understanding the numbers, species, sizes, and arrangement of trees in parking lots.

Like many cities, Raleigh, North Carolina, U.S., has enacted regulations that specify how trees are to be grown in and around parking lots, with the intent of providing aesthetic, economic, and environmental benefits (City of Raleigh 2009). The goal of the study authors was to characterize the overall structure (species, size, number per acre) of trees within the interiors of parking lots in Raleigh, and determine how this composition varies

* among parking lots of differing size and shape,

* between planting spaces that contain trees that appear to have been preserved during lot construction and those that were planted afterward, and

* among planting spaces of differing size and shape.

Any significant differences in composition would then allow identification of design approaches that are more likely to achieve the goals of the city's parking lot tree ordinance.

\section{MATERIALS AND METHODS}

\section{Study Area}

The $472 \mathrm{~km}^{2}$ study area consisted of the City of Raleigh, North Carolina and its extraterritorial jurisdiction (Figure 1). Raleigh is the 45th largest city in the United States, with a population of more than 400,000 (U.S. Census Bureau 2010). Raleigh passed an ordinance requiring trees to be planted in and around parking lots in 1987, for purposes including air purification, stormwater retention, groundwater recharge, aesthetic and economic improvement, energy conservation, and reduction of heat and noise (City of Raleigh 2009).

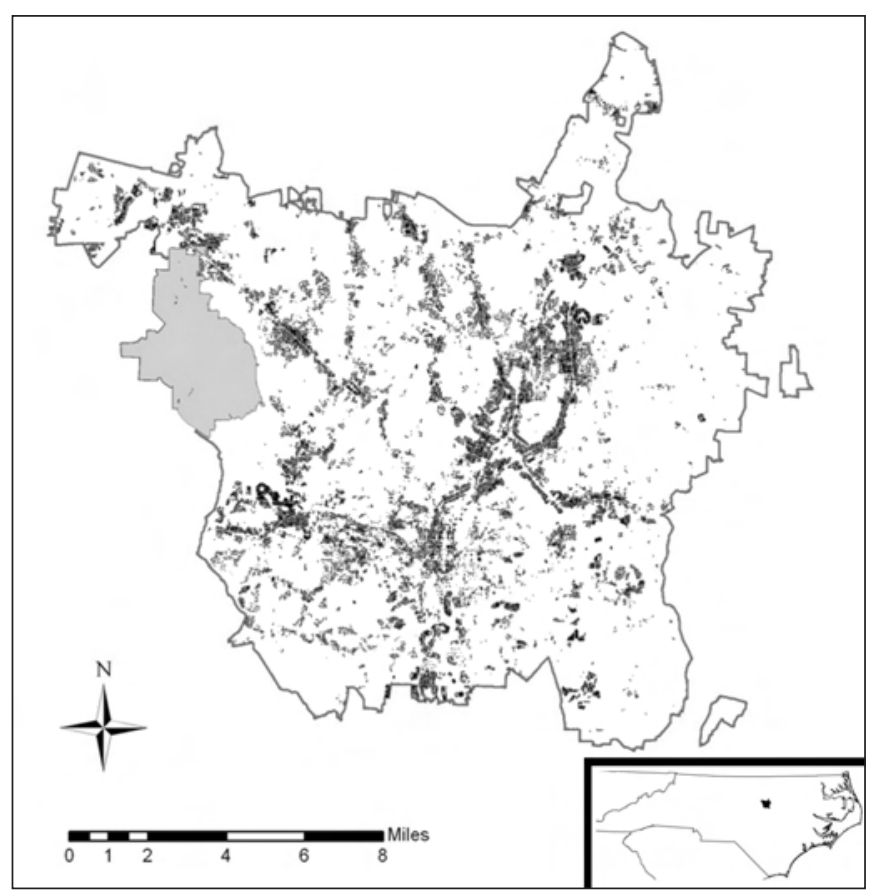

Figure 1. Map of parking lots in the study area (black/shaded). Parking lots cover approximately 28.2 km$^{2}$ in the City of Raleigh's planning jurisdiction. For comparison, Umstead State Park (22 $\mathbf{k m}^{2}$ ) is shaded in gray. Inset: The state of North Carolina. The darkened spot represents the City of Raleigh.

\section{Site Selection and Sample Design}

Raleigh has made publicly available a series of digital planimetric maps of the parking lots as they existed in 2006 (Wake County GIS 2010). Researchers verified the accuracy of these maps using six-inch resolution color aerial orthophotos. Entrances and exits, parking spaces, the top levels of some parking decks, and loading and unloading areas were included in these maps; non-paved areas within each parking lot were accurately delineated as empty spaces within the parking lot surface.

The authors used a two-stage cluster sampling scheme to estimate characteristics of trees in Raleigh's parking lots (Avery and Burkhart 2002). In the first stage, the authors classified and selected parking lots that contained nonpaved areas that were likely to contain trees, and in the second stage these nonpaved areas were selected for sampling.

The majority of trees in parking lots in the study area were found in discrete, nonpaved areas, which were identified in the digital planimetric maps using ArcGIS 9.2 (ESRI 2009). Nonpaved areas containing buildings were removed from further consideration; the remaining areas were classified as planting spaces.

Most small parking lots can satisfy Raleigh's ordinance without providing space for trees within the lot interior. Because the focus of this study was on the trees in the interior of parking lots, the more than $8,000(80 \%)$ parking lots that did not contain at least one planting space were assumed to contain no trees and were not sampled. For the remaining 1,982 parking lots, six quantities were calculated.

1. Total area of the parking lot $\left(\mathrm{m}^{2}\right)$.

2. Compactness ratio of the parking lot

$$
\left[K \text {, defined as } K=\frac{2 \sqrt{ } \pi(\text { Area })}{\text { Perimeter }}\right. \text {, }
$$

where Area is the area of the parking lot and Perimeter is the perimeter of the lot (Forman 1995). This ratio compares the perimeter of a parking lot (the denominator) to the perimeter of a circle with the same area (the numerator), and decreases from one for circular shapes toward zero for increasingly long, thin shapes.

3. Number of planting spaces in the parking lot.

4. Total area of all planting spaces in the parking lot $\left(\mathrm{m}^{2}\right)$.

5. Ratio of parking lot area per planting space (i.e., \#1 / \#3).

6. Ratio of parking lot area to planting space area (i.e., \#1 / \#4).

These six values were used to perform a multivariate clustering using SAS JMP 7 (SAS Institute 2007). The authors identified four classes of parking lots: simple (small lot size with an average number of planting spaces), intensive (small lot size with more or larger planting spaces), extensive (large lot size with a compact shape), and elongated (large lot size with less compact shape). Parking lots were selected randomly from each of the four resulting classes for field sampling, with a total 110 parking lots sampled (Stage 1, Table 1).

For all planting spaces, the authors calculated the area, perimeter, and a compactness ratio $(\mathrm{K})$, as previously defined. The area of each planting space was plotted against its compactness ratio and classified into four types on the basis of its size and shape (Figure 2). Using this plot, researchers defined four types of planting spaces: islands, rows, chunks, and slivers (Figure 3). In each sampled parking lot, 12 planting spaces or $20 \%$ of all planting spaces, whichever was greater, were subsampled, stratified by planting space type. At least one of each type of planting space present in a 
lot was subsampled (Stage 2). Within sampled parking lots, planting spaces that were not completely surrounded by pavement or which were not publicly accessible were removed. Geographic data were adjusted as needed to reflect current field conditions.

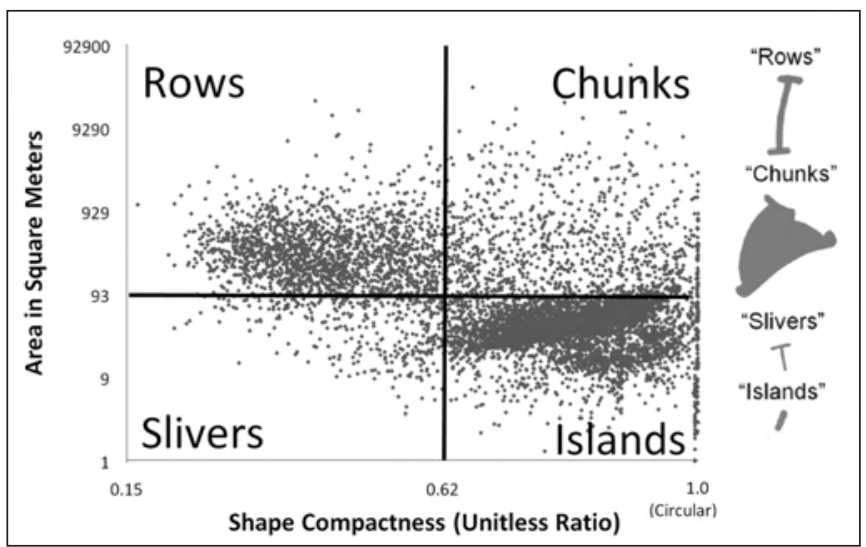

Figure 2. Four planting space types were defined by their area and shape compactness. Islands, defined as planting spaces with a compactness ratio $(K)$ greater than $\mathbf{0 . 6 2}$ and an area of less than $93 \mathrm{~m}^{2}$, were the most common planting space in the study area.

\section{Field Measurements}

For each woody plant having a stem with a diameter greater than $2.54 \mathrm{~cm}$ at breast height $(1.37 \mathrm{~m})$, the following measurements were collected: tree height $(\mathrm{m})$, height to crown base $(\mathrm{m})$, diameter at breast height $(\mathrm{cm})$, crown diameter in two perpendicular directions (m), and species (or genus if species could not be determined). In four very large planting spaces containing more than one hundred trees each, trees were subsampled using circular plots.

Of the 501 sampled planting spaces, 41 contained at least one tree whose size, species, and location indicated that the tree was likely growing in a field or forest before the parking lot and associated buildings were constructed. These were classified as preserved planting spaces (Figure 3). All other planting spaces were labeled as "designed" planting spaces.

\section{Data Analysis}

The study authors created a geodatabase using field measurements and geospatial data for each planting space and parking lot. Each parking lot and planting space was weighted using the inverse probability of it being sampled. Each tree was assigned the weight of the planting space in which it was found. In the four subsampled planting spaces, each tree was further weighted with the ratio of the total area of the planting space to the area of all subsampled plots within that planting space. The resulting weighted values provided estimates of species composition

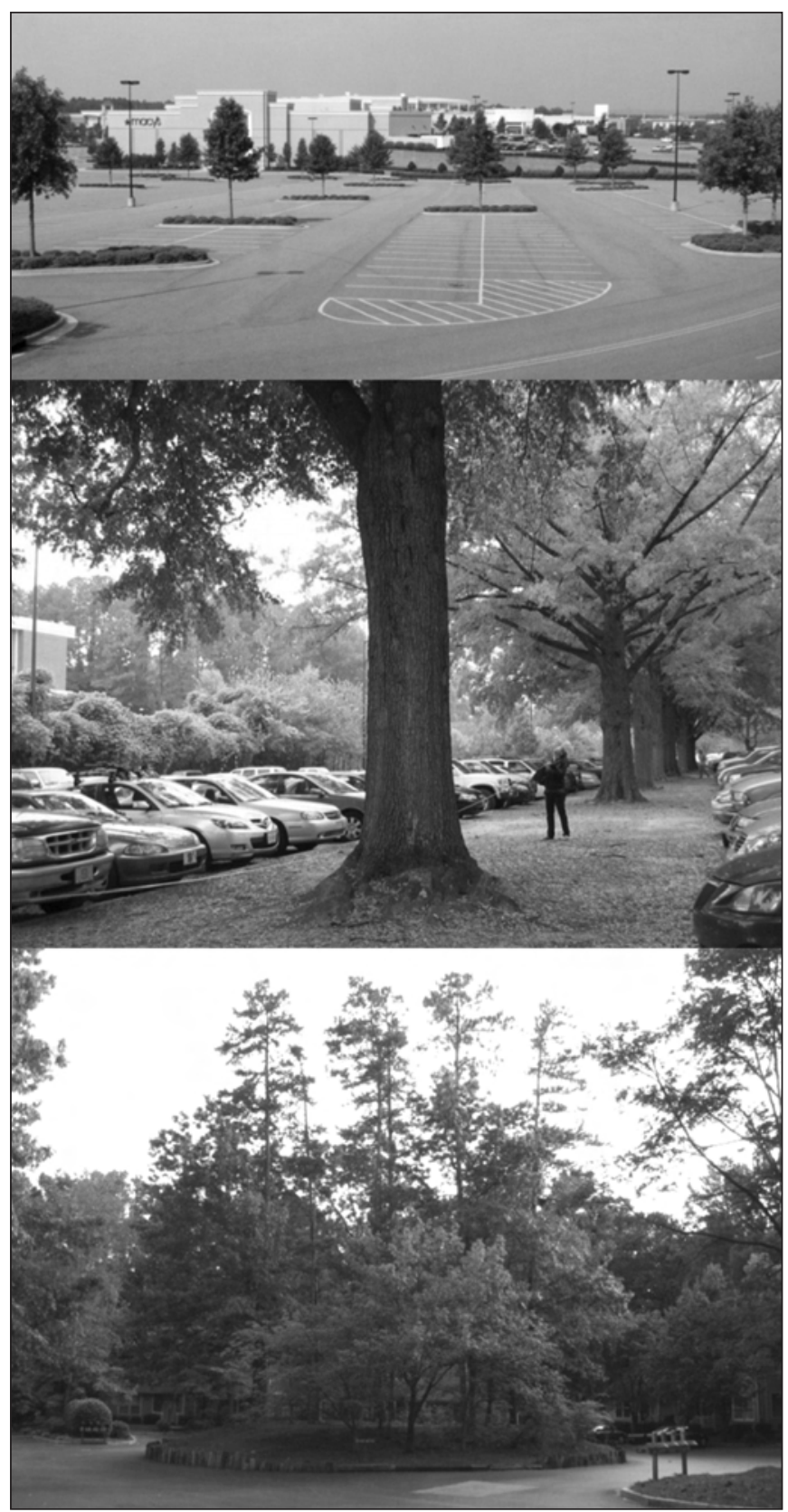

Figure 3. Examples of planting spaces in parking lots: (top) Designed islands with single trees and decorative shrubs; (middle) A designed row containing mature willow oaks. Although large, these trees were intentionally planted in the early 1960s; (bottom) These pines and hardwoods appear to be the same age as trees in nearby forests. When a parking lot was built around these trees, a preserved chunk was created.

Table 1. The four classes of parking lots sampled.

\begin{tabular}{llcc}
\hline Class & Description & $\begin{array}{c}\text { Number of lots } \\
\text { sampled }\end{array}$ & $\begin{array}{c}\text { Estimated number of lots } \\
\text { in study area }\end{array}$ \\
\hline Simple & $\begin{array}{l}\text { Small size, average in size and } \\
\text { number of planting spaces } \\
\text { Small size, more planting spaces or } \\
\text { Intensive }\end{array}$ & 46 & 908 \\
Extensive & Larger planting spaces & 22 & 270 \\
Elongated & Low compactness, large size & 14 & 56 \\
Total & & 28 & 409 \\
\hline
\end{tabular}


and tree density. Weighted values were used to perform one-way analysis of variance (ANOVA) on the basis of planting area type and parking lot class, followed by pairwise comparisons where significant. This sampling scheme provides a representative sample of (a) publicly accessible planting spaces within the interiors of parking lots in Raleigh's planning jurisdiction, (b) the trees growing within these planting spaces, and (c) the parking lots in which these planting spaces were found. Results were considered to be significant at $\alpha=0.05$ for all statistical tests.

\section{RESULTS}

Parking lots were estimated to cover approximately $28.2 \mathrm{~km}^{2}$ $(5.97 \%)$ of the study area. Most of the city's parking lot area occurs in three land use zones: industrial (33\%), multifamily

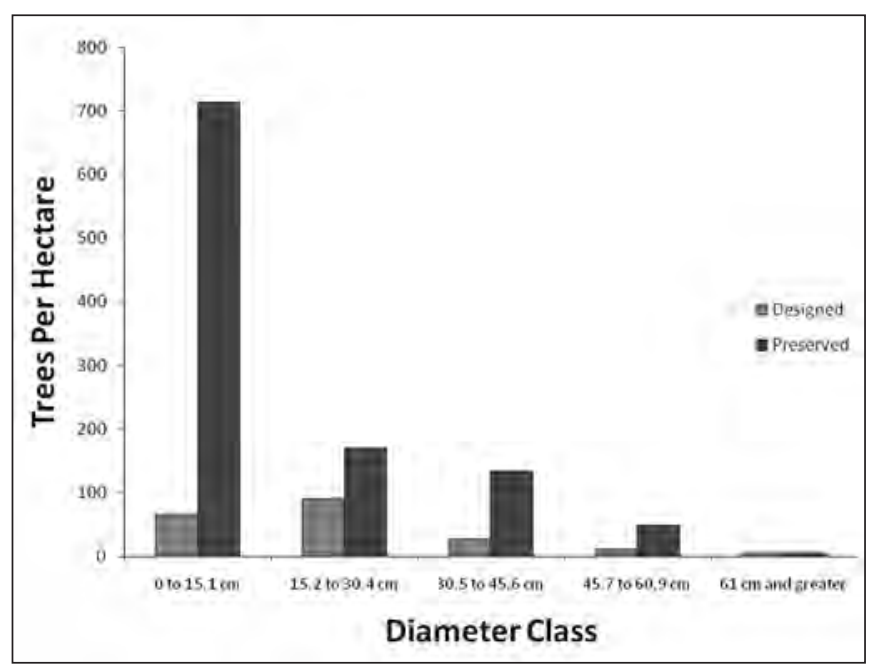

Figure 4. Estimated density of trees by diameter class and planting space type. residential $(17.7 \%)$, and offices and institutions (17.4\%). Extensive lots contained significantly more trees per lot than the other three classes of lots $(P<0.05)$. There were no significant differences in total trees per lot among the remaining three lot classes. No significant differences were found in the basal area, canopy area, or height per tree or the per-unit-area number of trees, basal area, or canopy among the four lot classes.

Significant differences were found in forest composition between planting spaces that were preserved or designed and on the basis of their size and shape. Preserved planting spaces contained significantly more trees, basal area, and canopy per area than designed planting spaces (Table 2), and differed in dominant species and diameter distribution (Figure 4).

In Raleigh, islands were the most common planting space, followed by rows. Designed rows had significantly greater canopy per tree, basal area per tree, and significantly fewer trees per hectare than designed islands (Table 3). Trees in designed chunks and rows were significantly taller than trees in designed slivers. Preserved islands contained greater per-unit area canopy cover and basal area than preserved chunks and rows (Table 4). Mean tree size varied with respect to planting space type and origin (Table 5).

Researchers estimated 44,000 $\pm 24,000$ trees (95\% confidence interval) were growing within these parking lots, representing at least 60 different tree species. Of these, $18,000 \pm 7,600$ trees were in designed planting spaces, and $26,000 \pm 23,000$ trees were in preserved planting spaces. This is a small fraction $(\sim 1 \%)$ of the 17 million \pm 7.4 million trees estimated to be growing within the entire study area (Hess et al. 2008). Of the 60 tree species identified, 46 species were native to the study area and represent a mix of upland and lowland species, including evergreens and deciduous species. An estimated 5,800 trees, or $31 \%$ of trees in designed planting spaces, represent 14 species that are not native to the area. Crapemyrtle (Lagerstro-

Table 2. Comparison of forest composition in preserved and designed planting spaces. All ranges are reported with $95 \%$ confidence.

\begin{tabular}{|c|c|c|}
\hline & $\begin{array}{l}\text { Preserved planting spaces } \\
(\mathrm{n}=41)\end{array}$ & $\begin{array}{l}\text { Designed planting spaces } \\
(\mathrm{n}=460)\end{array}$ \\
\hline Top 10 species & $\begin{array}{l}\text { Sweetgum }(39 \%, \mathrm{n}=87) \\
\text { (Liquidambar styraciflua) } \\
\text { Loblolly pine }(16 \%, \mathrm{n}=144) \\
\text { (Pinus taeda) } \\
\text { Shortleaf pine }(9 \%, \mathrm{n}=50) \\
\text { (Pinus echinata) } \\
\text { Eastern red cedar }(7 \%, \mathrm{n}=10) \\
(\text { Juniperus virginiana) } \\
\text { Sourwood }(5 \%, \mathrm{n}=5) \\
\text { (Oxydendrum arboreum) } \\
\text { White oak }(5 \%, \mathrm{n}=4) \\
\text { (Quercus alba) } \\
\text { Red maple }(4 \%, \mathrm{n}=38) \\
\text { (Acer rubrum) } \\
\text { Northern red oak }(2 \%, \mathrm{n}=23) \\
\text { (Quercus rubra) } \\
\text { Black cherry }(2 \%, \mathrm{n}=7) \\
\text { (Prunus serotina) } \\
\text { Black oak }(2 \%, \mathrm{n}=9) \\
\text { (Quercus velutina) }\end{array}$ & $\begin{array}{l}\text { Red maple }(27 \%, \mathrm{n}=362) \\
(\text { Acer rubrum }) \\
\text { Willow oak }(17 \%, \mathrm{n}=239) \\
\text { (Quercus phellos) } \\
\text { Crapemyrtle }(11 \%, \mathrm{n}=141) \\
\text { (Lagerstroemia indica) } \\
\text { Northern red oak }(8 \%, \mathrm{n}=32) \\
\text { (Quercus rubra) } \\
\text { Chinese elm }(4 \%, \mathrm{n}=41) \\
(\text { Ulmus parvifolia) } \\
\text { Callery pear }(3 \%, \mathrm{n}=27) \\
(\text { Pyrus calleryana }) \\
\text { American holly }(2 \%, \mathrm{n}=24) \\
\text { (Ilex opaca) } \\
\text { Japanese zelkova }(2 \%, \mathrm{n}=25) \\
(\text { Zelkova serrata }) \\
\text { Wax myrtle }(2 \%, \mathrm{n}=30) \\
\text { (Morella cerifera) } \\
\text { Green ash }(2 \%, \mathrm{n}=21) \\
(\text { Fraxinus pennsylvanica) }\end{array}$ \\
\hline Mean basal area per hectare & $47.8 \pm 6.7 \mathrm{~m}^{2}$ & $13.3 \pm 1.8 \mathrm{~m}^{2}$ \\
\hline Mean canopy area per planting space area & $165 \pm 34 \%$ & $82 \pm 10 \%$ \\
\hline Mean of average tree height per planting space & $14 \pm 1 \mathrm{~m}$ & $7.6 \pm 0.3 \mathrm{~m}$ \\
\hline Mean trees per hectare of planting space (TPH) & $808 \pm 126 \mathrm{TPH}$ & $334 \pm 37 \mathrm{TPH}$ \\
\hline
\end{tabular}


Table 3. Pairwise comparison of composition among four classes of designed planting spaces, following significant one-way ANOVA.

\begin{tabular}{|c|c|c|c|}
\hline & ...than chunks & ...than islands & ...than rows \\
\hline Islands have... & $\begin{array}{l}\text { No significant } \\
\text { differences }\end{array}$ & $\mathrm{X}$ & $X$ \\
\hline Slivers have... & $\begin{array}{l}\text { Smaller mean tree } \\
\text { height }(\mathrm{p}=0.0019) \\
(\text { slivers }=5.0 \mathrm{~m}, \\
\text { chunks }=8.7 \mathrm{~m})\end{array}$ & No significant differences & $\begin{array}{l}\text { Smaller mean tree height } \\
(\mathrm{p}=0.0024) \\
(\text { slivers }=5.0 \mathrm{~m}, \\
\text { rows }=8.2 \mathrm{~m})\end{array}$ \\
\hline
\end{tabular}

Table 4. Pairwise comparison of composition among three types of preserved planting spaces following significant one-way ANOVA.

\begin{tabular}{|c|c|c|}
\hline & ...than chunks & ...than islands \\
\hline Islands have... & $\begin{array}{l}\text { Greater canopy per area }(\mathrm{p}<0.0001) \\
\text { (islands }=321 \%, \text { chunks }=109 \%), \\
\text { Greater basal area per area }(\mathrm{p}<0.0001) \\
\text { (islands }=89.5 \mathrm{~m}^{2} \text { per hectare, } \\
\text { chunks }=34.4 \mathrm{~m}^{2} \text { per hectare) }\end{array}$ & $\mathrm{X}$ \\
\hline Rows have... & No significant differences. & $\begin{array}{l}\text { Less canopy per area } \\
(\mathrm{p}=0.0007) \\
(\text { rows }=155 \%, \text { islands }=321 \%), \\
\text { Less basal area per area } \\
(\mathrm{p}<0.0001) \\
\left(\text { rows }=42.5 \mathrm{~m}^{2} \text { per hectare, }\right. \\
\left.\text { islands }=89.5 \mathrm{~m}^{2} \text { per hectare }\right)\end{array}$ \\
\hline
\end{tabular}

Table 5. Mean tree size by planting space type. All ranges are reported with $95 \%$ confidence.

\begin{tabular}{|c|c|c|c|c|c|c|c|}
\hline & \multicolumn{4}{|l|}{ Designed } & \multicolumn{3}{|l|}{ Preserved } \\
\hline & Chunks & Islands & Rows & Slivers & Chunks & Islands & Rows \\
\hline Diameter $(\mathrm{cm})$ & $24.2 \pm 2.3$ & $20.1 \pm 1.4$ & $24.8 \pm 1.1$ & $14.6 \pm 4.4$ & $12.0 \pm 1.4$ & $22.7 \pm 7.6$ & $20.8 \pm 2.1$ \\
\hline Height (m) & $8.4 \pm 0.7$ & $7.4 \pm 0.4$ & $8.5 \pm 0.3$ & $5.2 \pm 1.3$ & $8.1 \pm 0.6$ & $11.7 \pm 3.4$ & $11.4 \pm 0.9$ \\
\hline Canopy area $\left(\mathrm{m}^{2}\right)$ & $37.9 \pm 7.0$ & $24.5 \pm 4.2$ & $38.3 \pm 3.3$ & $12.3 \pm 13$ & $7.7 \pm 1.8$ & $21.4 \pm 10.0$ & $17.4 \pm 2.8$ \\
\hline
\end{tabular}

mia indica) was the most common non-native species, and is estimated to represent almost half of non-native trees.

\section{DISCUSSION}

Raleigh's parking lots can contain tens of thousands of trees representing many different species. While the high variability in the data allows only a rough estimate of the overall number of parking lot trees in the study area, the methods used should provide more precise information if resources allow a larger portion of the population to be sampled.

The composition of trees in Raleigh's parking lots was correlated with the size, shape, and origin of the planting spaces within the lots, but not with the size or shape of the parking lots themselves. This correlation does not imply that these factors cause trees to grow faster, or reach larger sizes, nor does this snapshot study distinguish the effects of these factors from others, such as tree age and species, owner preferences, soil properties, or maintenance practices.

\section{Preserving versus Planting Trees in Parking Lots}

There were clear differences between preserved and designed planting spaces. Preserved spaces were dominated by upland species, while planted spaces contain mostly bottomland species. If compared to an upland piedmont hardwood forest, a representative hectare of preserved planting spaces would be stocked at more than $110 \%\left(47.8 \mathrm{~m}^{2}\right.$ basal area per ha/ 809 trees per hectare), while a representative hectare of designed planting spaces would be only $60 \%$ stocked $\left(13.3 \mathrm{~m}^{2}\right.$ basal area per ha, 334 trees per hectare) (U.S. Forest Service 1999). Some preserved spaces contained a very high density of small diameter trees that can block lines of sight and decrease area aesthetics, they may therefore warrant thinning (Anderson 
and Stokes 1989). Some planted spaces had trees that were removed and not yet replaced. Others exhibited poor arboricultural practices, such as constricting guy wires, girdling roots, and excessive mulching. While both approaches showed the need for maintenance to improve value, neither was clearly optimal for realizing the benefits of Raleigh's ordinance.

\section{Size and Shape of Planting Spaces}

Among designed planting spaces, islands were the most common in the study area, yet larger trees were growing in rows. The larger basal area and canopy area of trees in rows could be due to numerous factors, including differences in tree density, species choice, tree age, use of irrigation, or fertilizer applications. While controlled studies would be needed to test these effects, it is suspected that rows provide a better environment for healthy root growth (McPherson 2001; Grabosky and Gilman 2004; Celestian and Martin 2005; Smiley et al. 2006; Wolf 2009). While islands may constrain roots, rows provide more room to grow.

There are additional reasons to build parking lots with trees planted in rows:

* A row of mature tree canopies, oriented appropriately, can shade a row of parking spaces throughout the day better than trees in scattered islands. This would help to extend pavement life (McPherson and Muchnick 2005) and reduce the emission of volatile organic compounds from fuel tanks (Scott et al. 1999).

* A row of trees can provide a safe, shaded path for pedestrians and cyclists (Adams 2006).

* The long shape of rows is compatible with bioswales: wide, gently sloping, vegetated ditches that can help to control stormwater while supporting attractive vegetation (McPherson 2001; Wolf 2009).

* The cost of concrete curbs, irrigation lines, and maintenance can be reduced by using a few large rows instead of many scattered islands.

* Rows can support multiple trees, and the spacing between trees can be controlled over time. As trees die or are outcompeted by neighbors, they can be removed and neighboring trees can make use of this space. This helps to maximize canopy coverage and minimizes the impact of the loss of any individual tree.

Therefore, the study authors recommend that parking lot ordinances allow and encourage parking lot designers to create large, linear planting spaces containing multiple trees, rather than the scattered, raised islands that were the most common planting space in Raleigh.

\section{Species Choice}

Species choice is likely to have a lasting effect on the benefits of this resource. Crapemyrtles and heavily pruned waxmyrtles (Morella cerifera) and hollies (Ilex $\mathrm{spp}$.) were commonly planted in parking lots throughout the study area, but are ineffective at providing most of the environmental benefits enumerated in Raleigh's ordinance. Willow oaks (Quercus phellos) appear to be an outstanding parking lot tree for this area, exhibiting almost no serious health problems and reaching large sizes (Figure 3). Willow oaks comprised more than half of the trees observed in designed planting spaces that had reached $10.7 \mathrm{~m}$ tall and 9.1 $\mathrm{m}$ in canopy diameter, Raleigh's goal for mature parking lot trees. Of the 260 willow oaks observed, 135 (52\%) met this goal.

While red maple (Acer rubrum) was the most commonly planted species, researchers did not observe any outstanding characteristics that would explain this popularity. Only 8 of 400 red maple trees observed in this study had reached the mature size goals specified in the ordinance. Further research is needed to determine if the average red maple tree is likely to reach the size specified in Raleigh's ordinance when planted within a parking lot. Red maples are vulnerable to mechanical damage, trunk rot fungi, and stem diseases (Hutnik and Yawney 1961), and severe trunk damage was observed in many red maples in this study. Additionally, many different insects can reduce red maples' growth, make the trees vulnerable to decay, or help kill weakened trees (Hutnik and Yawney 1961). Maples are also very good hosts for Asian longhorned beetle (Raupp et al. 2006).

A diverse mix of trees could enhance seasonal aesthetics and provide landmarks for motorists to use in locating parked vehicles. Several researchers have recommended that each species comprise no more than 5\%-15\% of street tree populations to protect long-term forest health (Clark et al. 1997; Raupp et al 2006). The study authors recommend avoiding monocultures in parking lots and that ordinances specify the maximum percentage of parking lot trees that can be met by a single species. The level of diversity recommended for street trees could be met easily in parking lots in the Raleigh area using species that are commercially available and well-adapted to growth in parking lots.

\section{CONCLUSIONS}

Parking lots in a city may contain tens of thousands of trees, representing a unique and interesting component of the urban forest. Periodic sampling of these trees allows urban forest managers to understand the composition of this resource and can help to shape policy and improve design. While the size and shape of parking lots had no apparent relationship to the composition of trees within them, the decisions made during the design of planting spaces do appear to have a lasting effect on the benefits provided. The effectiveness of a city's parking lot tree ordinance may be determined largely when designers decide to preserve or plant trees, choose the size and shape of these planting spaces, and select tree species. The study authors suggest that developers work with arborists to identify trees that can be preserved, and where possible, preserve multiple large trees in large spaces rather than individual trees in islands. Where trees must be planted, researchers suggest incorporating a diversity of large-growing species in large contiguous rows instead of isolated islands. By providing information to parking lot owners and designers, urban forest managers can help to ensure that their cities' goals are being realized.

Acknowledgments. The Garden Club of America provided financial support for this research. Louise Alexander, Laura Fieselman, Diana Keto, Joan Louie, Susan McIntyre, Corey Shake, Jasmine Shaw, Megan Shaw, and Elizabeth Wood assisted with data collection. 


\section{LITERATURE CITED}

Adams, A.G. 2006. Between auto(mobile) and building: A study of pedestrian oriented parking lots. M. Architecture Thesis, Virginia Polytechnic Institute and State University, Blacksburg, Virginia, U.S.

Akbari, H., and L.S. Rose. 2001a. Characterizing the Fabric of the Urban Environment: A Case Study of Salt Lake City, Utah. LBNL-47851. Lawrence Berkeley National Laboratory, Berkeley, California, U.S.

Akbari, H., and L.S. Rose. 2001b. Characterizing the Fabric of the Urban Environment: A Case Study of Chicago, Illinois. LBNL-49275. Lawrence Berkeley National Laboratory, Berkeley, California, U.S.

Akbari, H., L.S. Rose, and H. Taha. 1999. Characterizing the Fabric of the Urban Environment: A Case Study of Sacramento, California. LBNL-44688. Lawrence Berkeley National Laboratory, Berkeley, California, U.S.

Albanese, B., and G. Matlack. 1998. Utilization of parking lots in Hattiesburg, Mississippi, USA, and impacts on local streams. Environmental Management 24(2):265-271.

Anderson, L.M., and G.S. Stokes. 1989. Planting in parking lots to improve perceived attractiveness and security. Journal of Arboriculture 15(1):7-10.

Arnold Jr., C.L., and C. J. Gibbons. 1996. Impervious surface coverage: the emergence of a key environmental indicator. Journal of the American Planning Association 62(2):243.

Asaeda, T., V.T. Ca, and A. Wake. 1996. Heat storage of pavement and its effect on the lower atmosphere. Atmospheric Environment 30(3):413-427.

Avery, T.E., and H.E. Burkhart. 2002. Forest Measurements. Fifth Edition. McGraw-Hill, New York, New York, U.S. 456 pp.

Beckett, K.P., P.H. Freer-Smith, and G. Taylor. 1998. Urban woodlands: Their role in reducing the effects of particulate pollution. Environmental Pollution 99(3):347.

Celestian, S.B., and C.A. Martin. 2004. Rhizosphere, surface, and air temperature patterns at parking lots in Phoenix Arizona, U.S. Journal of Arboriculture 30(4): 245-252.

Celestian, S.B., and C.A. Martin. 2005. Effects of parking lot location on size and physiology of four southwestern U.S. landscape trees. Journal of Arboriculture 31(4):191-197.

City of Raleigh. 2009. Code of Ordinances. Accessed August 12, 2009. <www.municode.com/Resources/gateway.asp?pid=10312\&sid=33>

Clark, J.J., N.P. Matheny, G. Cross, and V. Wake. 1997. A model of urban forest sustainability. Journal of Arboriculture 23(1):17-30.

Davis, A.Y., B.C. Pijanowski, K. D. Robinson, and P.B. Engel. 2010. Estimating parking lot footprints in the Upper Great Lakes Region of the USA. Landscape and Urban Planning 96(2):68-77.

EPA (U.S. Environmental Protection Agency). 2007. Cars, Trucks, Buses, and "Nonroad" Equipment. The Plain English Guide to the Clean Air Act. August 29, 2008. Accessed August 12, 2009. <www.epa.gov/ air/caa/peg/carstrucks.html>

ESRI (Environmental Systems Resource Institute). 2009. ArcMap 9.2. ESRI, Redlands, California, U.S.

Forman, R.T. 1995. Land Mosaics: The ecology of landscapes and regions. Cambridge University Press, Cambridge. 632 pp.

Grabosky, J., and E. Gilman. 2004. Measurement and prediction of tree growth reduction from tree planting space design in established parking lots. Journal of Arboriculture 30(3):154-164.

Grimmond, C.S.B., and T.R. Oke. 1999. Heat storage in urban areas: local-scale observations and evaluation of a simple model. Journal of Applied Meteorology 38(7):922-940.

Hahn, H.H., and R. Pfeifer. 1994. The contribution of parked vehicle emissions to the pollution of urban run-off. Science of the Total Environment 146-147:525-533.
Hammer, T.R. 1972. Stream channel enlargement due to urbanization. Water Resources Research 8(6):1530-1540.

Heisler, G.M., and R.H. Grant. 2000. Ultraviolet radiation in urban ecosystems with consideration of effects on human health. Urban Ecosystems 4(3):193-230.

Hess, G.R., J. Clayton, C. Dustin, M. Hall, L. Hausfather, T. Israel, H. Litzenberger, B. Ryan, S. Schwarzer, T. Stanforth, and L. Wicker. 2008. Assessing Urban Forest Effects and Values: Raleigh's Urban Forest. Accessed August 25, 2009. <http://courses.ncsu.edu/nr300/ common/project2008/products/Report.2008.06.30.pdf>

Hope, D., M.W. Naegeli, A.H. Chan, and N.B. Grimm. 2004. Nutrients on asphalt parking surfaces in an urban environment. Water, Air, \& Soil Pollution 4(2-3):371-390.

Hutnik, R.J., and H.W. Yawney. 1961. Silvical characteristics of red maple (Acer rubrum). Station Paper NE-142. U.S. Forest Service, Upper Darby, Pennsylvania, U.S. 18 pp. Accessed September 29, 2010 $<$ http://nrs.fs.fed.us/pubs/sp/sp_ne142.pdf>

Jackson, K.T. 1996. All the world's a mall: reflections on the social and economic consequences of the American shopping center. The American Historical Review 101(4):1111-1121.

Kunstler, J.H. 1996. Home from nowhere. The Atlantic Monthly 278(3):43-66.

Mahler, B.J., P.C. vanMetre, T.J. Bashara, J.T. Wilson, and D.A. Johns. 2005. Parking lot sealcoat: An unrecognized source of urban polycyclic aromatic hydrocarbons. Environmental Science \& Technology 39(15):5560-5566.

McPherson, E.G. 2001. Sacramento's parking lot shading ordinance: Environmental and economic costs of compliance. Landscape and Urban Planning 57:105-123.

McPherson, E.G., and J. Muchnick. 2005. Effect of street tree shade on asphalt concrete pavement performance. Journal of Arboriculture 31(6):303.

McPherson, E.G., J.R. Simpson, P.J. Peper, S.L. Gardner, K.E. Vargas, S.E. Maco, and Q. Xiao 2005. Piedmont Community Tree Guide: Benefits, Costs, and Strategic Planting. USDA Forest Service General Technical Report PSW-GTR-200. 99 pp.

Nowak, D.J. 2008. Assessing urban forest structure: summary and conclusions. Journal of Arboriculture 34(6)391-392.

Nowak, D.J., D.E. Crane, and J.C. Stevens. 2006. Air pollution removal by urban trees and shrubs in the United States. Urban Forestry and Urban Greening 4(3):115.

Raupp, M.J., A.B. Cumming, and E.C. Raupp. 2006. Street tree diversity in Eastern North America and its potential for tree loss to exotic borers. Journal of Arboriculture 32(6):297-304.

Rose, L.S., H. Akbari, and H. Taha. 2003. Characterizing the Fabric of the Urban Environment: A Case Study of Greater Houston, Texas. LBNL-51448. Lawrence Berkeley National Laboratory, Berkeley, California, U.S.

Rowntree, R.A., and D.J. Nowak. 1991. Quantifying the role of urban forests in removing atmospheric carbon dioxide. Journal of Arboriculture 17(10):269.

SAS Institute, Inc. 2007. JMP, Version 7. Cary, North Carolina, U.S.

Schroeder, H.W., J.F. Dwyer, and J. Flannigan. 2009. Big trees in the urban forest: an endangered resource worth saving. Arborist News.

Scott, K.I., J.R. Simpson, and E.G. McPherson. 1999. Effects of tree cover on parking lot microclimate and vehicle emissions. Journal of Arboriculture 25(3):129.

Shoup, D.C., and American Planning Association. 2005. The High Cost of Free Parking. Planners Press, American Planning Association, Chicago. $734 \mathrm{pp}$.

Smiley, E.T., L. Calfee, B.R. Fraedich, and E.J. Smiley. 2006. Comparison of structural and nonstructural soils for trees surrounded by pavement. Journal of Arboriculture 32(4):164-169. 
Stenstrom, M.K., G.S. Silverman, and T.A. Bursztynsky. 1984. Oil and grease in urban stormwaters. Journal of Environmental Engineering 110(1):58-72.

U.S. Census Bureau. 2010. Annual Estimates of the Resident Population for Incorporated Places over 100,000, Ranked by July 1, 2009 Population: April 1, 2000 to July 1, 2009 (SUB-EST2009-01). Accessed September 29, 2010. <www.census.gov/popest/cities/SUBEST2009.html>

U.S. Forest Service. 1999. Reference handbook for Foresters. NAFR-15. Accessed September 30, 2010. <www.na.fs.fed.us/pubs/refhbk/refhbk.pdf>

Wake County GIS. 2010. Download Data. Accessed August 25, 2009. <www.wakegov.com/gis/download_data.htm>

Wolf, K.L. 2009. Strip malls, city trees, and community values. Arboriculture \& Urban Forestry 35(1):33-40.

Xiao, Q.F., E.G. McPherson, S.L. Ustin, M.E. Grisner, and J.R. Simpson. 2000. Winter rainfall interception by two mature open-grown trees in Davis, California. Hydrological Processes 14(4):763.

Evan M. Keto (corresponding author)

301 S. Brooks Street

Wake Forest, North Carolina 27587, U.S.

evanketo@hotmail.com

Melissa R. McHale

North Carolina State University

Department of Forestry \& Environmental Resources

Box 8008

Raleigh, North Carolina 27695, U.S.

George R. Hess

North Carolina State University

Department of Forestry \& Environmental Resources

Box 8008

Raleigh, North Carolina 27695, U.S.

Bronson P. Bullock

North Carolina State University

Department of Forestry \& Environmental Resources

Box 8008

Raleigh, North Carolina 27695, U.S.

Gary B. Blank

North Carolina State University

Department of Forestry \& Environmental Resources

Box 8008

Raleigh, North Carolina 27695, U.S.

Résumé. Les arbres fournissent d'importants bénéfices environnementaux, économiques et sociaux qui peuvent aider à diminuer les effets négatifs associés aux aires de stationnement. Plusieurs villes reconnaissent qu'augmenter l'espace en arbres dans les stationnements est bénéfique et ont adopté des règlements qui établissent des paramètres minimum pour la plantation d'arbres. Cependant, il n'est pas clair si la plantation d'arbres dans les stationnements a permis d'atteindre les objectifs initialement recherchés par les villes. Les auteurs de cette étude ont échantillonné des arbres parmi des stationnements à Raleigh en Caroline du Sud aux États-Unis dans le but de déterminer comment la composition en espèces et la structure de la forêt urbaine varient par rapport à la dimension du stationnement, sa forme et son design. Au moyen d'un système d'échantillonnage par grappes en deux stades, les stationnements de Raleigh comptaient $44000 \pm 24000$ arbres (intervalle de confiance à 95\%). Aucune différence en composition d'arbres n'a été expliquée en fonction de la dimension ou de la forme des stationnements. Les espaces de plantation qui ont été préservés au sein des stationnements lors de leur construction avaient plus d'arbres et les arbres avaient une couronne ainsi qu'une surface terrière plus importantes à l'hectare que les espaces créés de toute pièce au sein desquels le nombre, l'espacement et les espèces d'arbres avaient fait l'objet d'une planification. Au sein des espaces de plantation ayant fait l'objet d'un design, les arbres au sein des alignements larges et linéaires avaient une couronne et une surface terrière par arbre plus élevées, mais ils y étaient moins abondants quantitativement à l'hectare et ce, par rapport aux îlots circulaires. Ces résultats suggèrent que les décisions arrêtées lors du processus de design peuvent avoir des effets permanents à long terme sur la structure et la fonction de cette portion de la forêt urbaine.

Zusammenfassung. Bäume liefern wichtige ökologische, ökonomische und soziale Vorteile, die dazu beitragen können, die negativen Effekte von Parkplätzen auszugleichen. Viele Städte erkennen, dass die Bereitstellung von Platz für Baumpflanzungen an Parkplätzen von Vorteil ist und sie haben Verordnungen geschaffen, die die Minimal-Anforderungen für Baumpflanzungen vorschreiben. Dennoch ist es nicht eindeutig, ob Baumpflanzungen an Parkplätzen die Ziele der urbanen Baumkronenbedeckung, die von den Kommunen ursprünglich vorgesehen waren, erreichen. Die Autoren dieser Studie erhoben die Stammdaten von parkplatzbegleitenden Bäumen in Raleigh, Nord-Carolina, um zu bestimmen, wie die Baumartenzusammensetzung und die urbane Forststruktur in Bezug auf die Parkplatzgröße, -form und -design variiert. Mit einem zweistufigen Cluster-System fand man heraus, dass Raleigh s Parkplätze 44.000+/-24.000 Bäume (95 \% Vertrauensintervall) enthalten. Durch die Größe oder Form der Parkflächen konnten sich keine Unterschiede in der Baumartenzusammensetzung erklären lassen. Pflanzflächen zwischen den Parkflächen, die während er Bauphase erhalten wurden, enthielten mehr Bäume, mehr Kronenfläche und Basalfläche pro Hektar als die gestalteten Pflanzflächen, die denen die Anzahl, Artenwahl und Abstand zueinander vorbestimmt waren. Unter den gestalteten Pflanzflächen hatten die großen linearen Reihen eine größere kronen- und Basalfläche pro Baum aber weniger Bäume pro Hektar als kleinere, runde Pflanzinseln. Diese Ergebnisse legen nahe, dass die Entscheidungen während des Gestaltungsprozesses einen langanhaltenden Einfluss auf die Struktur und Funktion auf diesen Teil des Stadtgrüns haben können.

Resumen. Los árboles proveen importantes beneficios ambientales, económicos y sociales que pueden ayudar a compensar los efectos negativos en los lotes de estacionamientos. Muchas ciudades reconocen que añadiendo espacio para los árboles en aparcamientos resulta benéfico y han creado regulaciones que dictan requerimientos mínimos para plantación de árboles. Sin embargo, no es claro si las plantaciones en lotes de estacionamientos alcanzan los objetivos de densas copas de los árboles urbanos inicialmente imaginados por estas comunidades. Los autores del estudio muestrearon árboles en lotes de aparcamiento en Raleigh, North Carolina, U.S., para determinar cómo la composición de especies y la estructura del bosque urbano varía con respecto al tamaño, forma y diseño del lote de aparcamiento. Usando un esquema de muestreo de conglomerados de dos estados, se encontró que los lotes de aparcamiento de Raleigh contienen 24,000 $\pm 44,000$ árboles (95\% intervalo de confianza). No hubo diferencias en composición por especies de árboles explicadas por el tamaño o forma de los lotes. Se encontró que los espacios de plantación dentro de los lotes de aparcamiento, que fueron preservados durante la construcción, tuvieron más árboles, dosel y área basal por hectárea que los espacios de plantación diseñados en los cuales el número, espacio y especies de árboles fueron prescritos. Entre los espacios de plantación diseñados las hileras grandes tuvieron mayores doseles y área basal por árbol pero hubo menos árboles por hectárea que las islas circulares pequeñas. Estos resultados sugieren que las decisiones hechas durante los procesos de diseño pueden tener efectos duraderos en la estructura y función de esta porción del bosque urbano. 